\title{
Identification of tumor-specific $T$ cell receptors from primary tumor-infiltrating lymphocytes
}

\author{
Hiroyuki Kishi*, Hiroshi Hamana, Kiyomi Shitaoka, Atsushi Muraguchi \\ From 30th Annual Meeting and Associated Programs of the Society for Immunotherapy of Cancer (SITC 2015) \\ National Harbor, MD, USA. 4-8 November 2015
}

Antigen-specific adaptive $\mathrm{T}$ cell therapy or $\mathrm{T}$ cell receptor (TCR) gene therapy is promising as a next generation tumor therapy. For the therapy, the production of tumorspecific $\mathrm{T}$ cells or their TCRs is prerequisite. Exploration of tumor-associated antigens, antigen-specific T cells or their TCR is usually restricted to the population with major HLA haplotypes, such as HLA-A24 for the Southeast Asian or HLA-A2 for Caucasian population. In this context, antigen-specific $\mathrm{T}$ cell therapy or TCR gene therapy is restrictive to those with major HLA haplotypes but is not beneficial for those with minor HLA haplotypes. In this study, we analyzed the TCR $\alpha \beta$ repertoire of tumorinfiltrating lymphocytes (TIL) of B16F10 melanoma in C57BL/6 mice at single cell levels. We found the clonal expansion of $\mathrm{T}$ cells in TILs, but not in splenic T cells and detected tumor-specific $\mathrm{T}$ cells in those clonally expanded cells. Our single cell analysis system may greatly contribute to analyze tumor-specific $\mathrm{T}$ cells without restriction in HLA haplotypes, thus leading to personalized tumor immunotherapy in the future.

Published: 4 November 2015

doi:10.1186/2051-1426-3-S2-P74

Cite this article as: Kishi et al:: Identification of tumor-specific T cell receptors from primary tumor-infiltrating lymphocytes. Journal for ImmunoTherapy of Cancer 2015 3(Suppl 2):P74.

University of Toyama, Toyama, Japan original work is properly cited. The Creative Commons Public Domain Dedication waiver (http://creativecommons.org/publicdomain/ zero/1.0/) applies to the data made available in this article, unless otherwise stated.

Submit your next manuscript to BioMed Central and take full advantage of:

- Convenient online submission

- Thorough peer review

- No space constraints or color figure charges

- Immediate publication on acceptance

- Inclusion in PubMed, CAS, Scopus and Google Scholar

- Research which is freely available for redistribution 